\title{
Bakonyi István
}

(Győr, Magyarország)

\section{AZ OROSZ MENTALITÁS EGYKOR ÉS MOST \\ (Változott-e a szépnem helyzete?)}

\begin{abstract}
In her book of 100 questions and 100 answers «Какие мы, русские?» (What Are We, Russians Like?) Alla Sergeyeva gives a real account of the XXI century mentality and stereotypes of behaviour. Like women in many other countries of the world Russian women consider taking care of the family hearth the most important in their lives. Their status during history was not enviable at all. One of the urgent problems of today is: why do they often make an effort to choose a foreign husband. Even today friendship and love "in the Russian way", intimacy and sex in Russian people's lives is an inexhaustible topic for discussion. It is important to study how the above concepts are expressed in the language and how they are translated into foreign languages.
\end{abstract}

Keywords: Russian soul, family hearth, emancipation, discrimination, foreign husband

A közelmúltban szerte a nagyvilágban, hazánkban és Oroszországban is reflektorfénybe került a nők helyzete, sorsuk alakulása a politikában, a munkahelyeken, az üzleti és a magánéletben.

A felmérések szerint Oroszországban a középvezetők közel 90 százalékát mint ahogyan oroszul is mondják - a „szépnem” képviselői teszik ki. A felső vezetőségben (pl. a Dumában) ez az arány már mindössze 8-10 százalék közötti, a hazai adatok hasonlóak.

A XXI. századi orosz mentalitás és a viselkedési sztereotípiák reális bemutatására vállalkozott Alla Szergejeva Какие мы, русские? (Milyenek vagyunk mi, oroszok?) címü, 100 kérdésre 100 részletes választ adó könyvében. A sokat vitatott „,rejtelmes orosz (női) lélek” elemzése mellett fontos szerepet kap a nők által ápolt családi tüzhely bemutatása is. A napjainkban egyre gyakrabban emlegetett, rejtelmes, titokzatos orosz női lélek fogalma köztudottan egyházi eredetü. A XX. századi orosz filozófusok, költők, írók több oldalról közelítették meg az orosz lélekkel kapcsolatos megfejthetetlen rejtélyeket, melyeket a történelmi körülmények miatt egyre több külföldi újságíró tüzött tollára. A hosszú évtizedekig tartó elszigeteltség következményeképpen a szovjet határokon kívül mindinkább az a szemlélet terjedt el, hogy az orosz lélekhez vezetö kulcsot, illetve kódot lehetetlen megtalálni.

Tyutesev orosz költő sokszor idézett verssorai is azt hangsúlyozzák, hogy Oroszországot ésszel megérteni nem lehet, hinni és bízni kell benne. Ugyanakkor a költőt is több kritika érte, hisz ép ésszel gyakran nem érthetjük a 
jó Istent, a gyengébb nem képviselőit, a klasszikus zenét vagy a modern festészet remekeit. A tjutcsevi hit elsősorban az együttérzésre, a teljes átélésre, esetleg empátiára utal, de ez gyakran kevésnek bizonyul.

A korábbi évszázadok, föként a középkor lovagi kultusza, majd a reneszánsz életöröm, a szexuális szabadosság csak részben tükröződik az orosz civilizációban. A nyugat-európai kultúra elsősorban az arisztokrácia köreihez jutott el. A XVIII. század elején a dán király például gratulált Nagy Péter cárnak, hogy „európaizálódott”, hisz nyilvánosan szeretőt tartott. Utódai, mindenek előtt II., azaz Nagy Katalin az imperátor méltó követője lett.

A XVII. században a feudális világszemlélet alapját a pravoszláv vallási hierarchia elve képezte: a világot Isten kormányozza, az államot az uralkodó, a családot pedig a férj. A Házirend (Domosztroj) a régi orosz családi életre vonatkozó intelmek gyüjteménye arra tanította a férjet, hogyan kell büntetnie a feleségét: kisebb vétségért korbácsütés járt, nagyobb engedetlenségért a férj már a feleség meztelen hátára mérhette ostorcsapásait.

A háztartáson kívül minden egyéb tevékenység elérhetetlen volt a nők számára. A változás Nagy Péter uralkodásával kezdődött el, aki komoly erőfeszítéseket tett arra vonatkozóan, hogy a nők részt vehessenek a nyilvános rendezvényeken, közös mulatságokon. Ezen kívül tervek születtek arról, hogy a nők részt vehessenek az oktatásban.

A reformok a XVIII. században folytatódtak. A fiatal házasulandóknak pl. nem kellett, hogy engedelmeskedjenek a szülöi akaratnak, mint korábban. 1724-ben erről cári törvény is született. A század második felében kezdett terjedni a nők házi taníttatása is.

A XIX. század második felében a radikális egyetemi mozgalmakhoz már nagyon sok nő is csatlakozott. Céljuk az volt, hogy a felsőoktatás számukra is elérhető legyen. A század végén a nők helyzete visszaesett a korábbi szintre, $\mathrm{s}$ továbbra is elzárkózva, kirekesztve éltek. Ezen az 1917-es forradalom próbált változtatni, a bolsevikok mindent megtettek a nők emancipációjáért. 1917 után minden 20 év feletti férfi és nő titkos és egyenlő szavazati jogot kapott. A siker azonban nem volt tartós.

Az 1920-as években az állam egyértelmüen arra biztatta a nőket, hogy vegyenek részt a termelésben, az iparban és a mezőgazdaságban is. Ugyanakkor az állam azt is megkövetelte a nőktől, hogy álljanak helyt anyaként és feleségként is. Az 1926-os törvényben az élettársi közösségben élők ugyanolyan jogokat kaptak, mint a házastársak. A válásnál elég volt, ha az egyik fél kérvényezte, a másik fél beleegyezésére sem volt szükség, őt levélben értesítették. Ezenkívül bevezették a törvényes és ingyenes abortuszt. Így a Szovjetunió lett a világ első olyan országa, ahol elfogadott volt a terhesség-megszakítás.

Az 1930-as években nagy változások következtek be a nők társadalmi szerepvállalásában. Növelni kellett a lakosságszámot, hiszen az éhínségek és az erőszakos kollektivizálás számos áldozatot követelt. A nőkre hirtelen anyaként lett szükség, s arra biztatták őket, hogy minél több gyermeket szüljenek. A 
média felhívta a nők figyelmét arra, hogy legyenek nőiesebbek. Propagálták a korábbi „burzsoá luxust” (manikürkészlet, divatos ruhák, kozmetikumok stb.). A propaganda fö üzenete az volt, hogy a társadalom alapja a család, ezért megnehezítették a válást, illegálissá tették az abortuszt.

$\mathrm{Az}$ 1930-as évek második felében nők ezrei váltak a nagy terror áldozatává. A vád ellenük az volt, hogy a nép ellenségeinek voltak feleségei, testvérei, gyermekei vagy csupán ismerősei. Sztálin még a legközelebbi munkatársai feleségeit is túszként tartotta koncentrációs táborban (pl. Molotov felesége).

Visszatérve a jelenlegi állapotokhoz, elmondhatjuk, hogy a nemzetközi emberjogi szervezet felmérései szerint az utóbbi évtizedekben Oroszországban naponta 36 ezer nőt ver meg a férje, vagy élettársa. A probléma forrása, hogy Oroszországban nem kezelik önálló büntényként a házasságon belüli erőszakot. Emiatt a nők körében is jellemző az alkoholizmus és a kábítószer-fogyasztás.

Az orosz szexuális kultúra jellemzői azonban a hazai hagyományok és a népi mentalitás alapján fejlődtek ki. Ezek legfontosabb vonásai: az intimitás és a meghittség, szívélyesség. Legnagyobb értéke az intim kapcsolatoknak van, amelyek semmiképpen sem türnek külső szemlélöt. Természetesen ez nem zárja ki, hogy nemcsak a párizsi, budapesti metrón, hanem a moszkvai utcákon sem ritka jelenség a hosszasan csókolózó ifjú pár.

Az orosz kultúrában elkülönül a szerelem és a szex fogalma. Míg ez utóbbi csupán biológiai kapcsolat, addig a szerelem oroszul a felek közötti önzetlen, szívélyes és együttérző kapcsolatot jelent, melynek során lemondanak az egoista, önző önmegvalósításról, az egyéni szabadság túlburjánzásáról. Az orosz gondolkodásmód szerint a szerelem ritkán ölt anyagi jelleget, bár ez napjainkban világszerte vitatott kérdés. Évszázadokon keresztül nemzedékek nevelkedtek a közmondásokban tükröződő népi bölcsességeken, mint pl.

"A kedvesemmel a kunyhóban is a Paradicsomban vagyok".

"A boldogságot meg nem vásárolhatod".

A. Szergejeva szerint is e bölcs mondatok jelenleg már aligha tünnek meggyőzőnek.

A közmondások és a hagyományos, jelenleg konzervatívnak minősíthető felfogás szerint a szerelmet a házasság követi. «Без жены дом - содом», azaz a feleség nélküli ház - zürzavar, kicsapongás, sőt „erkölcsi fertő”. A magyar változat vélhetően azt hangsúlyozza, hogy a család lelke a nő. Ugyanakkor a jelenlegi Oroszországban az elmúlt 20 év alatt csaknem felére csökkent a házasságkötések száma. Hazánkban az elmúlt 60 év alatt ez egyharmadára szorult vissza (1949-ben 108 ezer, 2009-ben 38 ezer). Egyre több fiatal választja a tartós együttélést, amit az orosz nyelv megdöbbentően „polgári házasságnak" (гражданский брак) nevez, minthogy a korábbi évszázadokban hivatalosnak az egyházi esküvőt ismerték el. Aligha vigasztaló az a tény, hogy a francia lakosság egynegyede jelenleg egyedül élő (szingli), míg Párizsban ez az arány 50\%-os. 
Köztudott, hogy az orosz nők helyzete napjainkban sem könnyü: 99\%-uk dolgozik, s emellett a családi túzhely ápolása, a második müszak is főként rájuk hárul. A férfiak, azaz a férjek tisztelik az évszázados hagyományokat, amelynek értelmében a családfő az otthoni munkából ritkán veszi ki a részét.

A XX. századi tragikus események (forradalom, üldöztetések, háború) következtében ezek az archaikus hagyományok erősödtek. Ezzel magyarázható az, hogy 1945 után egy érett férfira három nő jutott. A jelenlegi statisztikai adatok szerint Oroszországban ma is $\mathbf{1 0}$ millióval több nő van, mint férfi. A szép nem képviselői gyengédséggel, szinte anyai gondoskodással küzdenek a másik nem „meghódításáért”. Nem véletlenül emlegetik a következő viccet:

Milyen nemzetiségü volt Éva? Az olasz válasz szerint csodaszép, tehát olasz. Sajátjának tartja a francia is, hisz Éva könnyüvérü volt. Mindkét véleményt cáfolja azonban az orosz, hisz Éva kunyhóban élt, az almát kettéosztotta, mezitelenül járt, és a paradicsomban érezte magát, tehát csak orosz lehetett.

Sajnos a mai orosz Évák egyáltalán nem érzik magukat a paradicsomban. A háborút követő években eltörölték a gyermektartási díj fizetését. A statisztikai adatok szerint jelenleg is az elvált férjek csupán 12\%-a segíti gyermekei fejlődését. Még az ezredfordulót követő években is a gyermekek háromnegyedét egyedülálló anyák nevelik.

Ennél is meghökkentőbb az a világrekord, melyet az abortuszok számával vívott ki Oroszország: ott ez 20-szor több, mint az európai országokban. Egyáltalán nem irigylésre méltó a mai orosz nők helyzete. Függetlenségre, önállóságra törekednek, de erős a velük szemben alkalmazott diszkrimináció. $\mathrm{Pl}$. azonos munkáért kevesebb bért kapnak, bár ez jelenleg is vitatott kérdés. Ez a tendencia Magyarországon is megfigyelhető, hiszen a nők azonos pozícióban nálunk is kb. $20 \%$-kal kevesebbet keresnek, mint a férfiak. Ugyanakkor Oroszországban mindent megtesznek a női emancipáció erősítése érdekében, törekednek a munkahelyi karrier és a családi fészek problémáinak összehangolására. A prioritás kérdése természetesen még mindig vitatott, de az orosz nők többsége még napjainkban is a családi életet tartja elsődlegesnek.

A fenti adatok és tények ismeretében válik rendkívül aktuálissá az a társadalompolitikai kérdés, vajon miért igyekeznek külföldi férjet választani a mai orosz nők. Meglepő és tanulságos is egyben, hogy a válasz nem csupán az anyagi elönyökről szól.

Melyek tehát az okok, amelyek a külföldi férjválasztást indokolják.

1. Mindenek előtt a férfihiány. Oroszhonban az ezredforduló után is tízmillióval kevesebb a férfi.

2. Másodszor a szabad orosz férfiak többsége nem versenyképes, azaz sok közöttük a rokkant, alkoholista, munkanélküli, akik alacsony fizetésük miatt aligha lehetnek családfenntartók. A nyugati férjjelöltek külsőleg is jóval vonzóbbak: ápoltak, ritkán hangoskodnak, mosolygás közben nem rejtik el fogaikat, az orosz férfiaknál jóval „,charmosabbak”. 
3. Természetesen nem elhanyagolható a legfontosabb: a gazdasági helyzet sokak számára Oroszországban kevés előnyt nyújt, gyakran hiányzik az anyagi biztonság. Ez Nyugaton többnyire biztosítottnak tünik.

Másik oldalról felmerül a kérdés: miért kellenek az orosz hölgyek az amerikai, nyugat-európai uraknak, hisz más a mentalitásuk, gyakran a nyelvet és a kultúrát sem ismerik jól, s rengeteg az egyéni problémájuk.

A statisztikai adatok szerint az USA-ban, Nyugat-Európában jóval több a férfi (az USA-ban 8 millióval több), $\mathrm{s}$ mindemellett évente több milliós emigráns, föként egyedülálló férfi érkezik a világ minden részéröl. Mint minden nö, úgy többségében az orosz hölgyek is igyekeznek minél vonzóbbak lenni. Megőrzik "kulturális étvágyukat", tájékozottak az irodalom, a müvészet területén. Így népszerủek a külföldiekkel való házasságkötések. S az sem véletlen, hogy az orosz nagyvárosokban növekszik a nem mindig tisztességes munkát végző házasságközvetítő irodák száma.

A fentiek alapján jogosan merül fel a kérdés: sikeresek-e a külföldiekkel kötött házasságok? Pro és kontra számtalan példát ismerünk, pontos adatokkal nem rendelkezünk. A házas évek során a problémák hamarosan jelentkeznek. Angliában és Franciaországban az első jelzést a férj kapja, amikor a munkahelyén egyre kevesebb felelősségteljes megbízást, külföldi kiküldetést kap, lassan halad felfelé a hivatali ranglétrán. Egyre szükül a baráti kör, ami szintén nem javítja az otthoni helyzetet.

A válások szubjektív okai közül leglényegesebb, hogy az orosz nők egy idő után csalódnak a férjükben, hisz a nyugati álomvilág, a paradicsomi élet helyett gyakran szük lakások, s messze nem a pazar luxusautók kísérik életüket. Gyorsan szétfoszlik a megálmodott mítoszok világa.

$\mathrm{Az}$ orosz nők többségét kellemetlenül érinti a férjek takarékossága, "fukarsága", hisz nem hagyják, hogy a feleség pocsékolja a vizet, a villanyt, hogy órákig csevegjen telefonon. Egy idő után a feleség népes családjának gyakori látogatása sem örvendezteti meg az okosan gazdálkodni kívánó férjet.

Természetesen a kölcsönös csalódás minden házasságban előfordulhat. A megértést gátolhatják a nyelvi nehézségek, a gondolkodásmódban és viselkedésben rejlö eltérő sztereotípiák. Idegen nyelven nem mindig sikerül a partnereknek adekvátan, az adott szituációnak tökéletesen megfelelően kifejezniük magukat, s ennek eredménye a stressz, a meg nem értés, majd a kölcsönös elhidegülés. Ezt elkerülendő mindkét félnek alaposan meg kell ismernie társa nyelvét, kultúráját, mentalitását, hogy a külföldi férjjel kötött házasság valóban tartós és harmonikus legyen.

Alla Szergejeva könyve továbbra is a vitatémák kimeríthetetlen tárháza, hisz a barátság, a szerelem, az intimitás, a szex és házasság vagy együttélés egyre fontosabb szerepet játszik a mai orosz ember életében is. A kérdésekre adott válaszok a feldolgozás során gyakran komoly vitát provokálnak.

Mindezek ismeretében érdemi kutatást igényel a fenti témák nyelvi kifejezése, valamint ezek idegen nyelvre történő hű fordítása (рl. дом-содом), 
hogy az oroszul nem beszélő számára is maradéktalanul érthetők legyenek azok az információk, amelyek sajátosan az orosz nyelvü kulturális ismeretekhez kapcsolódnak.

\section{Irodalom}

Сергеева, А.В. (2006) Какие мы, русские? (100 вопросов - 100 ответов) Изд. Русский язык. Курсы.

http: //www.undp.ru/Gender_MDG_eng.pdf (2012.09.19) 